\title{
De-privatization in higher education: a conceptual approach
}

\author{
Marek Kwiek ${ }^{1}$
}

Published online: 18 August 2016

(C) The Author(s) 2016. This article is published with open access at Springerlink.com

\begin{abstract}
This paper seeks to conceptualize the processes of de-privatization in higher education. Trends of de-privatization (and contraction in enrolments) are highly interesting because they go against global trends of privatization (and educational expansion). Deprivatization means a decreasing role for the private component in the changing publicprivate dynamics. The paper studies its two dimensions (funding and provision) and distinguishes between seven potential empirical organizational/geographical levels of analysis. Empirically, the paper draws from data from Central Europe. The traditional dichotomous pairing of the public and the private is shown to still be useful in specific empirical contexts, despite it becoming blurred globally. Major approaches to privatization in higher education over the last two decades are rethought and redirected toward deprivatization. An empirically informed notion of de-privatization is being developed and its usefulness is briefly tested.
\end{abstract}

Keywords De-privatization - Educational expansion · Educational contraction ·

Privatization · Public funding · Public-private dynamics private higher education · Internal and external privatization

\section{Introduction}

This paper seeks to conceptualize the processes of de-privatization in higher education. Deprivatization goes against global trends of privatization and means a decreasing role for the private component in the changing public-private dynamics. The paper studies de-

Electronic supplementary material The online version of this article (doi:10.1007/s 10734-016-0047-3) contains supplementary material, which is available to authorized users.

Marek Kwiek

kwiekm@amu.edu.pl

1 Center for Public Policy Studies, UNESCO Chair in Institutional Research and Higher Education Policy, University of Poznan, Ul. Szamarzewskiego 89, 60-569 Poznan, Poland 
privatization through the two dimensions of funding and provision, and distinguishes between several potential empirical organizational/geographical levels of analysis (from a department level to a global one).

Research on privatization in higher education comes in three, largely separate strands: (1) privatization in general (especially in the US context of public universities, see Priest and St John 2006; Morphew and Eckel 2009), (2) private higher education (especially in the Latin American and European post-communist contexts of private sector growth, see Levy 1986, 2013; Slantcheva and Levy 2007; Kwiek 2016b), and (3) cost-sharing (in the context of public universities, see Johnstone 2006; Teixeira et al. 2006; Johnstone and Marcucci 2010; Heller and Callender 2013). I synthesize these three strands in this paper, focusing on the privatization agenda which I view as consisting of the changes in both public and private sectors and referring to private sector growth and the increasing use of cost-sharing in the public sector.

Surprisingly, in some parts of post-communist Europe (referred to here as "the region"), global assumptions about the ever-growing demand for higher education and the constant growth in enrolments - combined with assumptions about the increasing pressure to privatize higher education mostly for financial reasons (Priest et al. 2006: 7; Johnstone 2000: 1; Sanyal and Johnstone 2011: 160; Thornton 2012: 12-13)—seem not to hold. On the contrary, new public-private dynamics at work in such countries as Poland, Estonia, Romania and Bulgaria tend to suggest opposite processes (Curaj et al. 2015; OECD 2015): Privatization is not taken for granted any more, and college-age cohorts are declining for demographic reasons, as is the overall demand for higher education. There are more vacancies than candidates, in both public and private sectors. Consequently, the pressure to privatize the public sector and to expand the private sector is as low as never before in the post-1989 period.

Thus, higher education in parts of post-communist Europe is moving against two major global trends of private sector growth and cost-sharing (defined as the worldwide trend of educational costs being shifted "from a dominant reliance on governments to an increasing reliance on parents and students," Sanyal and Johnstone 2011: 160). The two trends are globally the weakest in Continental Europe (see Heller and Callender 2013) which is "one of the last hold-outs of free higher education" (Marcucci 2013: 19), and even weaker in the region. While privatization in an American context means "the substitution of tuition fee income for state support" and "the move toward more reliance on private funding for 'public' higher education" (Zusman 1999: 119), de-privatization as explored in this paper would mean exactly the opposite: the substitution of state support for tuition fee income and the move toward more reliance on public funding for public higher education (combined with private sector decline). These regional countertrends demand greater conceptual and empirical attention.

De-privatization processes-in terms of funding - refer to proportionally decreasing private funding in higher education, or its decreasing privateness, over time, and privatization processes refer to proportionally increasing private funding, or its increasing privateness, over time. A proportional approach to de-privatization (i.e., percentages of public and private finance) makes it easier to identify the direction of ongoing changes at various levels of analysis. In post-communist Europe, which empirically informs this paper, the dynamics have clearly been changing toward more publicness and less privateness in the last decade.

The paper is divided into the following sections: This introductory section is followed by second section on theoretical approaches to privatization (and de-privatization). Third section links the processes of expansion with privatization and those of contraction with 
de-privatization. Fourth section presents the operationalization and measurement of deprivatization, fifth section presents a data-based discussion, and final section presents conclusions.

\section{Theoretical approaches: privatization and de-privatization}

Privatization as a social science concept is used in broad and narrow senses. Theoretical and empirical research on privatization in a broad sense, developed mostly within political economy, political sciences and economics, has been historically focused on two parts of the world: the USA (as well as the United Kingdom, see Le Grande and Robinson 1984; Walker 1984; Starr 1989; Feigenbaum et al. 1998) and European transition post-communist countries (see Spulber 1997; Nelson et al. 1997). Conceptualizations of privatization in higher education though, that is privatization in a narrow sense, refer mostly to the USA (Johnstone 2000; Priest and St John 2006; Morphew and Eckel 2009; Fryar 2012), with a limited number of publications on other parts of the globe (such as Poland, Australia, China, and selected other Asian and African countries, see Marginson 1997b; Kwiek 2016a; Painter and Mok 2008; Mok 2011; and Wang 2014).

Narrowly defined, privatization means denationalization and refers to the transfer to private ownership of public assets; including sales of public land, infrastructure and enterprises (see Starr 1989; Spulber 1997; Belfield and Levin 2002). Privatization has different meanings at three levels: an "idea," "theory and rhetoric," and "political practice" (Starr 1989: 15); at the level of political practice, privatization is a fundamental "reordering of claims in society" and in its extreme forms-known from post-communist transition economies in the 1990s — an instrument of "class politics" (Starr 1989: 42-43). The links between privatization in its broad and narrow senses are close (Whitty and Power 2000; Kaplan 2009; Priest and St John 2006). The frontiers between public and private sectors are "not always easy to define or clear-cut" (Spulber 1997: 101). The terms "public" and "private" are politically crucial: They sum up a "whole structure of rules and expectations about the proper conduct and limits of the state" (Starr 1989: 42).

In general terms, any privatization proposal involves the "rolling back of the activities of the state" (Le Grande and Robinson 1984: 3). The state can involve itself in social and economic activities in any of the three ways: provision, subsidy or regulation; the state can provide a particular commodity, subsidize it, and regulate its provision. Therefore, in the case of higher education, its privatization would entail the reduction of state's role along these three dimensions - and de-privatization, by analogy, would entail the increase in its role along these dimensions. Privatization (and privatization in higher education) has also an important normative dimension, though: the role of the state and its services in democratic societies, which go far beyond provision, subsidy and regulation. The privatization agenda inevitably raises the questions of equitable access, intergenerational social mobility, and the individualistic nature of modern societies (by analogy, de-privatization also carries important social implications as it emerges from a different, more collective and less individualistic normative basis).

The role of the state in regulating higher education is globally on the rise (Altbach et al. 2010). This is not related to privatization processes, though, being part of a New Public Management "managerial revolution." Also in the region, privatization and de-privatization processes are linked to only two of the three Le Grand and Robinson dimensions: provision and subsidy. At the heart of the privatization, strategy was the assumption that 
the public sector was "wasteful, inefficient and unproductive" (Walker 1984: 30). While privatization at a political level is an ideology-de-privatization does not seem to have ideological overtones: It is linked to more mundane factors such as, most of all, declining demographics (see e.g. Kwiek 2013).

There is a lack of conceptual clarity in theorizing about privatization in higher education (Fryar 2012: 521), and the precise definition of the term remains "elusive" (Ikenberry 2009: 2). Consequently, privatization means "many things" (Altbach et al. 2010: 73) and it is a "nuanced phenomenon" (Eckel and Morphew 2009: 183). It has "neither an unequivocal definition nor absolute or delimited characteristics" (Gómez and Ordorika 2012: 219). Most common among discussions of privatization are its definition as the decline in state support for higher education (Teixeira 2012). The privatization theme has been extensively treated in the last two decades. For instance, privatization of public universities can be viewed as the decentralization of governmental control (Eckel and Morphew 2009: 190-191); shifts in public opinion about the value of higher education, as studied through a median voter model (Toutkoushian 2009: 74-75); decreases in public funding and increases in entrepreneurial activities within institutions (Ikenberry 2009: 5), and increased reliance on market mechanisms to govern higher education (McLendon and Mokher 2009: 25-26) or increases in competition for students and resources (Kaplan 2009: 128) - as Fryar (2012: 523) shows taking the single volume on "privatizing the public university" in an American context as an example (see Morphew and Eckel 2009). The deprivatization theme seems to have been heavily under-researched: It has been mentioned in passing only in several isolated instances (e.g., Painter and Mok 2008; Mok 2011).

Despite accounts in which the public and the private are increasingly viewed as "blurred" (both American, see Geiger 2007; Altbach et al. 2010; Sanyal and Johnstone 2011; and European, see Enders and Jongbloed 2007), in the region, a still sharp divide between public and private institutions, publicly supported and privately supported students, public sector students and private sector students, as well as between public and private sources of funding-is analytically useful. Despite the fact that in other parts of the world these tools may no longer be useful. The core of the post-1989 transformations from the public-private perspective was the emergence of the privates and the appearance of fee-paying students in the public sector.

I am using in this paper the two contrasted dimensions of the private (privateness) and the public (publicness) in higher education, following Levy in his studies on the private sector. He assumes that "the private-public distinction matters" (Levy 1986: 293) and that it is "strong" (Levy 2013: 3). In practical terms,

we count private and public by their juridical designation, which generally overlaps ownership: if an institution is legally public we count it (and its enrolment) as public, regardless of its degree of "privateness" in finance or administration (Levy 2013: 3).

Following Guy Neave (2008: 73), privatization can have two forms: direct (the private sector expansion) and indirect (the decreasing reliance on public revenues raised from taxes). While in Western Europe direct privatization occurred in selected countries only (especially in Portugal and Iceland), in the region direct privatization used to dominate. Neave (2008: 74) shows a nuanced picture in which there is a tripartite classification of "state," "non-state" and "private" institutions in Western Europe, with new publicly funded foundation-like institutions in Germany, Norway and Sweden-which does not apply to the region. I assume that the strong public-private distinction is useful for a study of de-privatization. Consequently, changes in higher education systems in two or more countries can be located along the two publicness-privateness continua-one for funding 
and the other for enrolments - and compared over time. Privatization and de-privatization may occur along either of the two dimensions or along both of them. In the region, deprivatization at the system level clearly occurs along both dimensions, but at the institutional level, the changes may go in different directions: There may be privatizing institutions in de-privatizing national systems, and privatizing faculties in de-privatizing individual institutions (as I show in fifth section based on empirical examples).

Privatization (and de-privatization) is highly context-sensitive (Marginson 1997b: 460), with different meanings in different jurisdictions. In the US, private-public boundaries have long been "blurry," and in global perspective "it seems common that private-public distinctiveness can diminish over time" (Levy 2008: 45). Therefore both concepts need to be nuanced. In some jurisdictions, the state contracts out the provision of higher education and research services, or buys them on behalf of consumers or society at large from universities regardless of their (public, private or foundation-like) legal status. Legally independent (private) corporations can provide publicly funded services under conditions tightly regulated by the state. Williams (2016: 131-133) argues that in Eastern Europe, China, and much of the English-speaking world, in the last quarter of a century higher education has shifted from being treated by governments as a "public service" to a "private commodity" subject to the laws of supply and demand.

Privatization and de-privatization are much more clear-cut in the region where there are clear public/private distinctions in ownership and resourcing: privates receive almost exclusively private funding (although their students are entitled to receive state-subsidized loans), and publics receive predominantly public funding (and are entitled to charge fees in most cases to "part-time" or "second-track" or "out of quota" students). In financing, public sectors in the region are still "truly public" and private sectors are "truly private" (as Levy referred to his Latin American cases, 1986: 293). Therefore, while "just dividing higher education into a 'public sector' and a 'private sector' is too simple" (Calhoun 2011: 3 ), in the region, it is much simpler due to short history of cost-sharing and clear-cut characteristics of the private sector. Globally, though, there are such ongoing nuanced processes as a decline in "privateness in private institutions" and the rising "privateness in public institutions" (Levy 2013: 16) —which mean, in terms of funding, more public (direct or indirect) subsidies in the former and more income from fees in the latter.

For a study of de-privatization, major research on privatization which turns out highly useful are works by Gareth Williams, Daniel C. Levy, Simon Marginson, D. Bruce Johnstone, and Roger L. Geiger. Williams (1996: 52) links privatization at an institutional level to driving costs down until all the resources of the university are devoted to "the most profitable income-generating activity open to it." Privatization therefore inevitably means the changing nature of the university in which economic survival and financial viability are becoming inseparable from its "mission." De-privatization, in contrast, would increasingly keep university missions away from income-generating activities (focused on outside private funding) and economic survival would emerge in the context of the growing competition for public funding in its diversified forms. Following Williams' distinction between the three aspects of privatization ("macro-privatization," "micro-privatization" i.e., market principles in university organization, and privatization as "the introduction of quasi markets into the allocation of public funds"): The macro-privatization in the region is in retreat but the micro-privatization is in full swing, as is privatization as the introduction of internal markets. Referring to Williams' (1996: 39-40) six versions of privatization at the institutional level, de-privatization in the region would mean publicly owned universities receiving decreasing shares of their income from student fees. 
Following Simon Marginson's (1997a: 36) description of privatization in enrolments (it occurs "when parents transfer their children from government to private schools"), deprivatization can be defined from another angle: as the process of students massively choosing public institutions over private institutions-which is exactly the empirical case in the region now. There are three major reasons for this change: first, public institutions are tuition-free (and private ones are tuition-based). Second, public institutions are being massively funded with both national and European Union structural funds under declining demographics, and therefore, they are becoming ever more accessible, with ever more vacancies (OECD 2015; Curaj et al. 2015). And third, after a quarter of a century, the private sector is still "in search of legitimacy" (Slantcheva and Levy 2007; Levy 2013: 9; Kwiek 2012, 2015b), prestige is still provided predominantly by the best public universities, and there is no "public sector failure" (Marginson 1997b: 477) which contributed to demand-absorbing private sector growth in the 1990s (see Kwiek 2016c).

Following Johnstone's (2000: 2) definition of privatization in higher education as a "direction or tendency on multiple dimensions" between two extremes: "high "publicness" "and "high "privateness" "toward the latter - the dimensions being (1) mission or purpose, (2) ownership, (3) source of revenue, (4) control by government, and (5) norms of management-I would define de-privatization as a shift along different dimensions toward the "high publicness" extreme on the continuum. In the region, two dimensions tend to indicate privatization (mission or purpose; and norms of management) and three tend to indicate de-privatization (ownership; source of revenue; and control by government). There can be shifts in different directions-or stability—along the different dimensions over time, depending on the level of analysis (bearing in mind that privatization-and deprivatization—are "relative and directional rather than absolute" [Feigenbaum et al. 1998: 9]). Management and governance are harder than finance to define as public or private (Levy 2008: 48) and should be measured with respect to both changing legislation and changing practices. The model Johnstone applied to the institutional level can also be applied to other levels of analysis. Geiger (2007: 140-141) defines privatization through its three aspects: (1) an increased reliance on private (rather than public) resources, (2) increasing cooperation with private industry, and (3) increase in the importance of private institutions (size, prestige or influence). Consequently, de-privatization would be (1) an increased reliance on public rather than private resources (particularly in supporting public institutions), (2) decreasing cooperation with private industry, and (3) decrease in the importance of private institutions. The second form of de-privatization does not find empirical confirmation in the region but the first and the third certainly do.

Finally, Levy (2013: 11-12) argues that private sector growth has been part of a "broad privatization" in higher education. De-privatization in this context would be the decline of private higher education (in terms of the number of institutions, nominal or proportional enrolments in the private sector, and nominal or proportional share of fee-based private funding in the system). He views the current public sector privatization as a response to the challenge posed by private higher education growth. "What happens in the public sectorby government action or from within public higher education-can have major effects on the size of the private sector" (Levy 2013: 7): In this sense, de-privatization influences both sectors as they are strongly interrelated. What he terms "expansionary policies" in public higher education do indeed lead in the region to proportional private sector decline (Levy 2013: 10). Table 1 summarizes definitions of de-privatization as derived from major privatization literature briefly discussed above.

A set of traditionally distinctive concepts of "public" and "private" still works well in the region: It enables a simplified conceptual apparatus to operationalize and measure de- 
privatization. In this part of Europe, as in Levy's (2008: 46) general observation, "for the most part, the public sector remains quite public whereas private institutions are privately financed and have governance and accountability profiles consistent with their funding and purpose." While privatization was a powerful conceptual tool to comprehend systemic changes in the 1990s (see Kwiek 2012), de-privatization may be a useful tool to comprehend recent and future changes. At the same time-changing the terrain from public and private resources and ownership to public and private outcomes and benefits from higher education - the public sector in the region is increasingly being reconceptualized as producing private outcomes, and the private sector increasingly attempts to reconceptualize itself as producing public outcomes. Of the two parallel processes, the former is much more advanced. In terms of outcomes, as Marginson (2007: 323) argues, national higher education systems produce "a mix of public and private goods" which is "highly variable and policy sensitive."

Marginson in his recent work (2016a, c) provides a highly useful conceptual framework to sort out the conceptual and empirical ambiguity of the concepts of public and private outcomes, drawing on his previous work on "markets" and "the public/private divide" and going beyond it (from Marginson 1997a to Marginson 2007). He combines two traditional distinctions (stemming from the state/non-state political approach and from the nonmarket/market economic approach) and suggests four political economies of higher education represented graphically in the form of four quadrants: Civil Society (I), Social Democracy (II), State Quasi-Market (III) and Commercial Market (IV). The ingenuity of this proposal is that "together, the economic and political modes constitute a more explanatory and more instrumental framework for operationalizing the public/private distinction in higher education, than either the economic or political mode can provide alone" (Marginson 2016c: 24). Referred to the region, higher education activities had been

Table 1 Summary: definitions of de-privatization based on major statements on privatization in higher education (1996-2013)

\begin{tabular}{|c|c|c|}
\hline Author & $\begin{array}{l}\text { Source of definition of } \\
\text { privatization }\end{array}$ & Definition of de-privatization, by analogy \\
\hline $\begin{array}{l}\text { Gareth } \\
\text { Williams }\end{array}$ & 1996: 52-53, 39-40 & $\begin{array}{l}\text { Keeping university missions away from income-generating } \\
\text { activities focused on outside private funding; economic survival } \\
\text { linked to the competition for diversified public funding; publicly } \\
\text { owned universities receive decreasing shares of their income } \\
\text { from student fees }\end{array}$ \\
\hline $\begin{array}{l}\text { Simon } \\
\text { Marginson }\end{array}$ & 1997a: 36, 1997b: 460 & $\begin{array}{l}\text { Students massively choosing public institutions over private } \\
\text { institutions; (proportionally) increased public funding of public } \\
\text { institutions }\end{array}$ \\
\hline $\begin{array}{l}\text { D. Bruce } \\
\text { Johnstone }\end{array}$ & 2000: 2 & $\begin{array}{l}\text { A shift along any or all of the five dimensions-(1) mission or } \\
\text { purpose, (2) ownership, (3) source of revenue, (4) control by } \\
\text { government, and (5) norms of management-toward the "high } \\
\text { publicness" extreme on the "high publicness"/"high } \\
\text { privateness" continuum }\end{array}$ \\
\hline $\begin{array}{l}\text { Roger L. } \\
\text { Geiger }\end{array}$ & 2007: 140-141 & $\begin{array}{l}\text { (1) an increased reliance on public rather than private resources } \\
\text { (particularly in supporting public institutions), (2) decreasing } \\
\text { cooperation with private industry, and (3) decrease in the } \\
\text { importance of private institutions }\end{array}$ \\
\hline $\begin{array}{l}\text { Daniel C. } \\
\text { Levy }\end{array}$ & 2013: $11-12$ & $\begin{array}{l}\text { The decline of private higher education (in terms of the number of } \\
\text { institutions and/or of nominal/proportional enrolments in the } \\
\text { private sector) }\end{array}$ \\
\hline
\end{tabular}


moved from Quadrant 2 to Quadrant 3 in the era of post-communist expansion, including demand-absorbing private sector growth-and seem to be gradually returning to Quadrant 2 in the current era of contraction, including ongoing private sector decline. An environment of quasi-market in (fee-based) student places is being turned into an environment of tuition-free places. Although Marginson does not refer to the processes of de-privatization, they share many characteristics of the move from an Anglophone-style Quadrant 3 to a Nordic-style Quadrant 2 in his analytical framework: higher education in the region, in his terms, would be gradually moving from State Quasi-Market to Social Democracy, in an opposite direction than in the rest of Europe.

\section{Expansion/growth and privatization-contraction/decline and de-privatization?}

Higher education research and policy literature over the last few decades has been focused on the growing worldwide demand: on ever increasing student numbers-and how to finance expanding systems (Johnstone and Marcucci 2010; Altbach et al. 2010). Growth and expansion were the words (Heller and Callender 2013; Marcucci 2013)_decline and contraction were not. A common global assumption has been "the massive quantitative expansion" and "the huge increases in projected enrolments," both calling for "massive and continuing increases in revenues" (Sanyal and Johnstone 2011: 159). Coping with "more students and less money" (Thornton 2012: 13) has been a global phenomenon. In the demographic context of formidable expansion-combined with political contexts of "permanent austerity" in public sector services and ideological contexts of New Public Management-privatization was the word. Privatization was thus viewed as a policy mechanism to meet the goal of increasing access in expanding systems (Priest and St John 2006: 248).

Privatization has become a necessity because of "budgetary problems created by massification with simultaneous reductions in public investment" (Altbach et al. 2010: 82). However, while across the non-European Western world and the developing world there has been a dramatic increase in the number of students combined with the limitations of the public purse, the region seems unaffected by these global trends and-consequently-by Thornton's "privatizing imperatives" (2012) prevalent in public universities across the Anglophone world (for cross-national quantitative studies of the academic profession in 11 European systems, see Kwiek 2015c, 2016c, on the internationalization of research and on European research elites, respectively).

The critical issue is demographics. The privatization-demographics and de-privatization-demographics links are key: privatization seems to be on the rise in expanding systems (that is, almost everywhere globally in the 2010s) with increasing demographics; but it might be in reverse in contracting systems with heavily declining demographics (that is, in Central and Eastern Europe). The vast majority of higher education research and policy literature refers to expansion and related rising financial commitments; however, there are also systematically contracting systems, with negative growth and, consequently, decreasing commitments: namely the region in question, the fastest aging societies in Europe.

Private higher education gets hit hard by slowing demand, and the greatest vulnerability is in the demand-absorbing subsector (Levy 2013: 6) that dominates the sector in the region. Also, the rationales for cost-sharing are different for contracting systems than for- 
as traditionally developed to fit-expanding systems. The states in the region are able to increase per student funding without increasing total funding - as the number of students systematically decreases. Levy draws a useful distinction between a "raw" decline private higher education in absolute numbers and a "proportional" decline-including where "the decline is fundamentally a function of large-scale fresh public growth" (Levy 2013: 14). The region represents both types of decline. Following Belfield and Levin's (2002: 29) argument that the first factor to explain privatization in education is as simple as "many parents want it," I argue that de-privatization occurs because many parents/students no longer "want it" (as much as they did one or two decades ago).

In the region, two forms of privatization occurred: the growing demand in the expansion period was to be met by both internal privatization of the public sector and external privatization through new private providers (see Kwiek 2010 for the distinction). Analogously, internal de-privatization is linked to ever-growing public funding in the public sector and an ever-growing share of publicly funded (tuition-free) students in this sector. Behind external de-privatization-or the gradual private sector decline in the regionthere are four interrelated driving forces: (1) declining demographics: the age cohorts for the standard age of studying have been declining for a decade, and are expected to do so in the future; (2) the demand-absorbing character of the private sector: it was the first to appear, the largest to emerge, and it is currently having the hardest time to survive; (3) the rigidity of emergent hierarchies of prestige: principal private goods provided by higher education are "positional goods" (Marginson 1997a: 38-46; Marginson 2007: 198-201) and demand-absorbing private institutions in the region allocate on average the lowest value status goods; and (4) the tuition-free character of the competing public sector: the fully fee-based private sector competes with basically tuition-free public sector. The combination of the four above driving forces endangers the very existence of private sectors in the region, making external de-privatization a globally interesting phenomenon.

\section{Operationalization and measurement of de-privatization}

The organization of higher education can be represented in terms of the two-dimensional relationship between the sources of funding and provision (see Fig. 1 below). The public provision of higher education (or enrolments) is shown in Cells $1 / 2$, and private provision in Cells 3/4; public funding is shown in Cells 1/3, and private funding is shown in Cells $2 / 4$. Privately provided higher education competes with that which is publicly provided wherever both occur in the system.

There are four theoretically pure cases: public provision and public funding (Cell 1), public provision and private funding (Cell 2), private provision and public funding (Cell 3), and private provision and private funding (Cell 4). A pure model of publicly funded and

Fig. 1 Modes of higher education provision and funding revised from Whitty and Power (2000)
Funding (in higher education)

\begin{tabular}{|c|c|}
\hline Public & Private \\
\hline 1 & 2 \\
\hline 3 & 4 \\
\hline
\end{tabular}


publicly provided higher education is located in Cell 1; and a pure model of privately funded and privately provided higher education is located in Cell 4. Privatization in higher education is, as Whitty and Power (2000: 94) describe it in terms of welfare services in general, "a multi-faceted set of processes rather than a straightforward movement out of Cell 1 into Cell 4." Similarly, de-privatization is not a straightforward movement out of Cell 4 into Cell 1. Each national system can be located within the four cells over time. Additionally, movements within cells (i.e., quantitative differences) and among cells (i.e., qualitative differences) over time can be shown. Thus de-privatization along the funding dimension is either a quantitative change within Cell 2 toward public, or a qualitative change from Cell 2 to Cell 1 (in the public sector). De-privatization along the provision dimension is either a quantitative change within Cell 3 toward public, or a qualitative change from Cell 3 to Cell 1 (assuming that "public" means "with the majority of public-sector students" and "private" means "with the majority of private-sector students"). By definition, a "pure" Cell 1 cannot be deprivatized (and a "pure" Cell 4 cannot be privatized).

For empirical purposes, both funding and provision dimensions can be better calibrated to capture the changing realities at any level over time using deciles (or percentiles). An empirical study of de-privatization makes sense if it is viewed as a process, or a difference in the location in the model between two times in the public/private dimension of funding and/or enrolments at one or more levels. For instance, a shift from a $40 \%$ privately funded institution to a $20 \%$ privately funded institution denotes de-privatization at an institutional level, as does a shift from $40 \%$ private enrolments to $20 \%$ private enrolments in an institution.

A two-dimensional relationship can be further developed to be used for multilevel analyses at different organizational/geographical levels. I suggest the following:

Level 1 Individual faculty/department

Level 2 Individual university

Level 3 National state/province

Level $4 a$ Higher education sectors: public sector

Level $4 b$ Higher education sectors: private sector

Level 5 National system (country)

Level 6 Continent/political region

Level 7 Global

Consequently, the two dimensions (provision and funding) can be analyzed at seven organizational/geographical levels. There are complicated multi-faceted interrelations between the dimensions of funding and provision at different levels. The direction of changes over time at a lower level can be different from the aggregated direction of changes at a higher level. For instance, the aggregated direction of changes at Level 2 (individual university) over time can differ from changes in its various components at Level 1 (individual faculty/department). While the university as a whole can be privatizing, selected faculties/departments may be de-privatizing, or the other way round, as we show in fifth section. In a similar vein, while at an aggregated Level 5 (national system/country), higher education can be de-privatizing, there may be selected public institutions which are actually privatizing, along funding, provision, or both dimensions. At each level, trends can be accompanied by countertrends (see Kwiek 2016a for a detailed study of Poland as a global countertrend).

The two extremes at a systemic level-(fully) public and (fully) private higher education-seem not to exist in pure forms in the OECD area or globally (among OECD member states only Greece is reported to have neither "government-dependent private" 
nor "independent private" institutions, OECD 2014: 413). De-privatization at any level means movement on the continuum in the direction of the (fully) public (and privatization, by analogy, means movement in the other direction).

From the perspective of funding, internal privatization and internal de-privatization occur in public sector institutions (with ever more or ever less, nominally and/or proportionally, private funding over time), and external privatization and external de-privatization occur in private sector institutions (with ever more or ever fewer private sector institutions and private sector funding from fees in the system over time). External deprivatization is not possible in systems in which the private sector (as defined by the OECD term: "independent private") does not exist (e.g., in Belgium, Finland, Greece, the United Kingdom, Hungary and Sweden in Europe, and Canada outside Europe, OECD 2014: 413). And from the perspective of provision, internal privatization and internal de-privatization refer to public sector institutions, and external privatization and external de-privatization refer to private sector institutions. Consequently, external de-privatization is not possible in systems in which the private sector does not exist.

\section{Data and brief discussion}

Two major political events had powerful impact on postcommunist European higher education: the collapse of communism in 1989 (leading to regained institutional autonomy and academic freedom) and the accession to the European Union in 2004 (leading to massive European funding, embracing of the Bologna Process and integration with European Higher Education and Research Areas). The 1990s were very tight in economic terms, and 2000s and beyond-were tight in demographic terms (see Kwiek 2012, 2015c). Central and Eastern European societies are among the fastest aging societies globally but their higher education systems have been ever more publicly funded in the last decade. Government expenditure per tertiary student in USD (in PPP) in 2002-2012 were on the rise in all 10 new EU member states (see Table 2 in Online Supplementary Materials, or OSM). The rise in enrolments in the region in 1990-2010 was globally one of the highest, and systems changed their character from "elite" to "mass" (and, as in Poland, to "universal," to use Marin Trow's classification; Poland became one of those "high participation systems" studied by Marginson (2016b: 17) which reach a $50 \%$ mark and "keep on going," similarly to Russia where "the partial privatization of costs" in higher education led to its universalization, albeit combined with weakening of social equality, see Smolentseva 2016: 7). From a global perspective, what was particularly interesting was the emergence of the private sector, virtually out of nowhere, mostly in its low-level demand-absorbing type (Levy 2013).

A good example of de-privatization is provided by Poland, the biggest system in the region: at an aggregated system level, Poland was systematically moving toward the fully private extreme on the public-private continuum in its expansion period of 1990-2005and in the other direction since 2006, in its contraction period, both in terms of funding and provision.

Processes of higher education change at a national system level in Poland can be defined as a transfer from a fully public system under the communist regime (1945-1989), to $a$ dual (mixed) public-private system in the massification and expansion period of 1990-2005 (with clear public dominance in terms of share of enrollments and prestige), to a de-privatizing system in transition in which the private sector and private funding are playing a decreasing role (2006-2016), and (possibly) to a de-privatized system, with a 


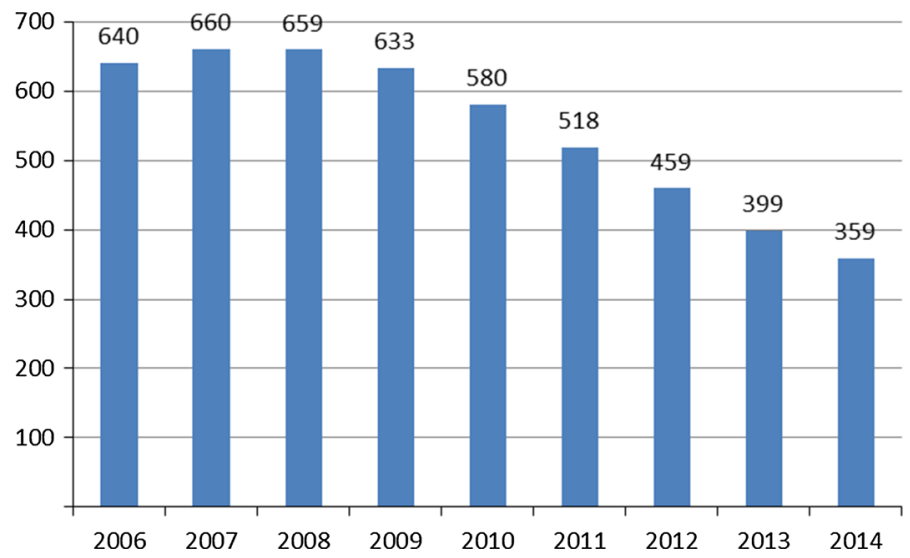

Fig. 2 Empirical example 1: De-privatization at Level 4b (Poland, private sector). The number of students in the private sector, 2006-2014 (in thousands). Own calculations based on GUS (2015) and its previous editions

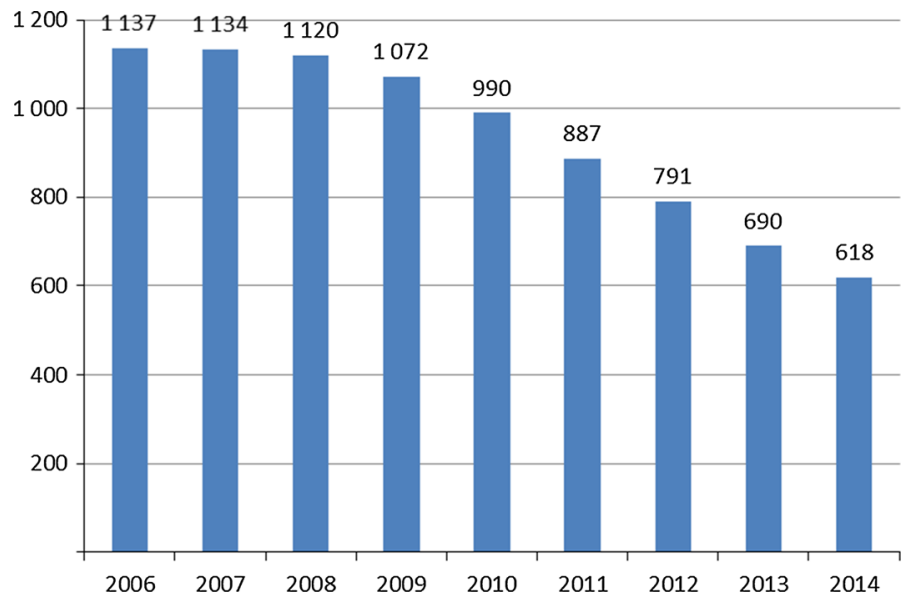

Fig. 3 Empirical example 2: De-privatization at Level 5 (country). The number of fee-paying students in public and private sectors in Poland combined, 2006-2014 (in thousands). Own calculations based on GUS (2015) and its previous editions

marginal role for the private sector with enrollments slightly above 10 percent and the dominant role for the public system and public funding (2017-2025 and beyond).

Table 1 shows various aspects of the two dimensions of de-privatization (provision and funding) for the period of 2006-2014 (historical data) and 2022 (projections). In all cases, the direction of aggregated changes is clearly toward de-privatization (see the last two columns in the table). The provision aspects of de-privatization include: the decreasing number of private higher education institutions; decreasing enrolments in the private sector; the decreasing number (and share) of fee-paying students in both sectors combined; the decreasing number (and share) of fee-paying students in the public sector; the increasing share of enrolments in the public sector; and the increasing share of tax-based (tuition-free) students in the public sector. A graphic presentation of selected changes in the provision aspects of de-privatization is given below in Figs. 2, 3, 4 and 5. 


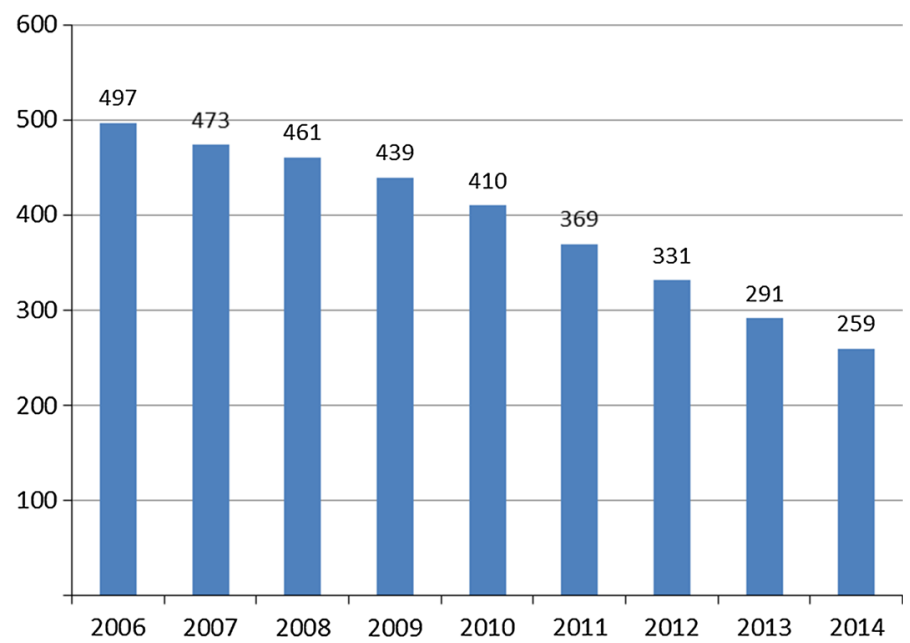

Fig. 4 Empirical example 3: De-privatization at Level 4a (Poland, public sector). The number of feepaying students in the public sector, 2006-2014 (in thousands). Own calculations based on GUS (2015) and its previous editions

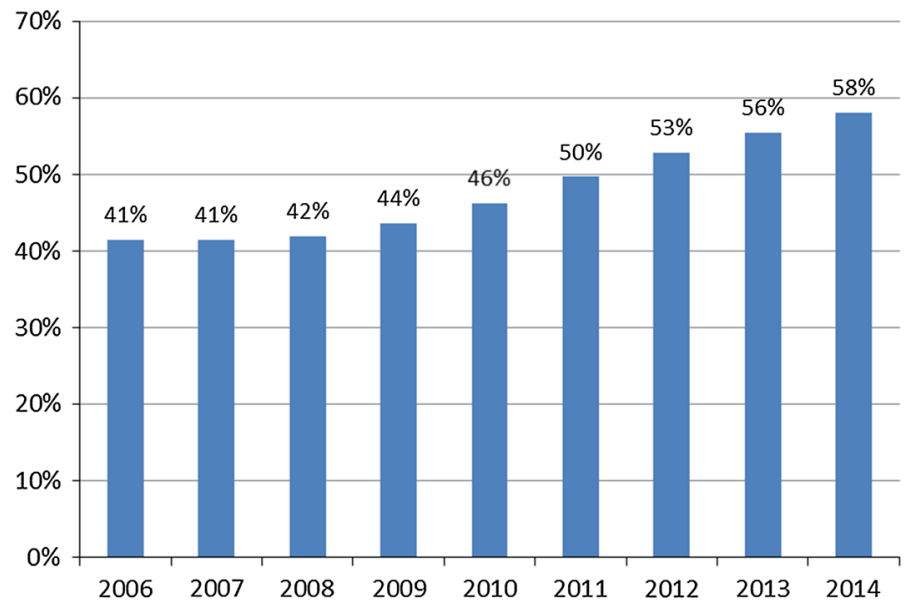

Fig. 5 Empirical example 4: De-privatization at Level 5 (country). The share of tax-based (tuition-free) students in the Polish system, 2006-2014 (in thousands). Own calculations based on GUS (2015) and its previous editions

The funding aspects of de-privatization include: the decreasing income from fees (from part-time students) in the public sector and in the private sector (from all students); the decreasing share of total income from fees (in public and private sectors combined) in total operating budgets of both sectors; the decreasing share of private income in the public sector in operating budget of the public sector; and the increasing share of public income (teaching only) in the public sector in operating budget of the public sector. Projections for 2022 confirm the direction of changes; what is more, processes of de-privatization are likely to intensify (see the column for 2022 in Table 2). A graphic presentation of selected changes in funding aspects of de-privatization is given below in Figs. 6 and 7. 


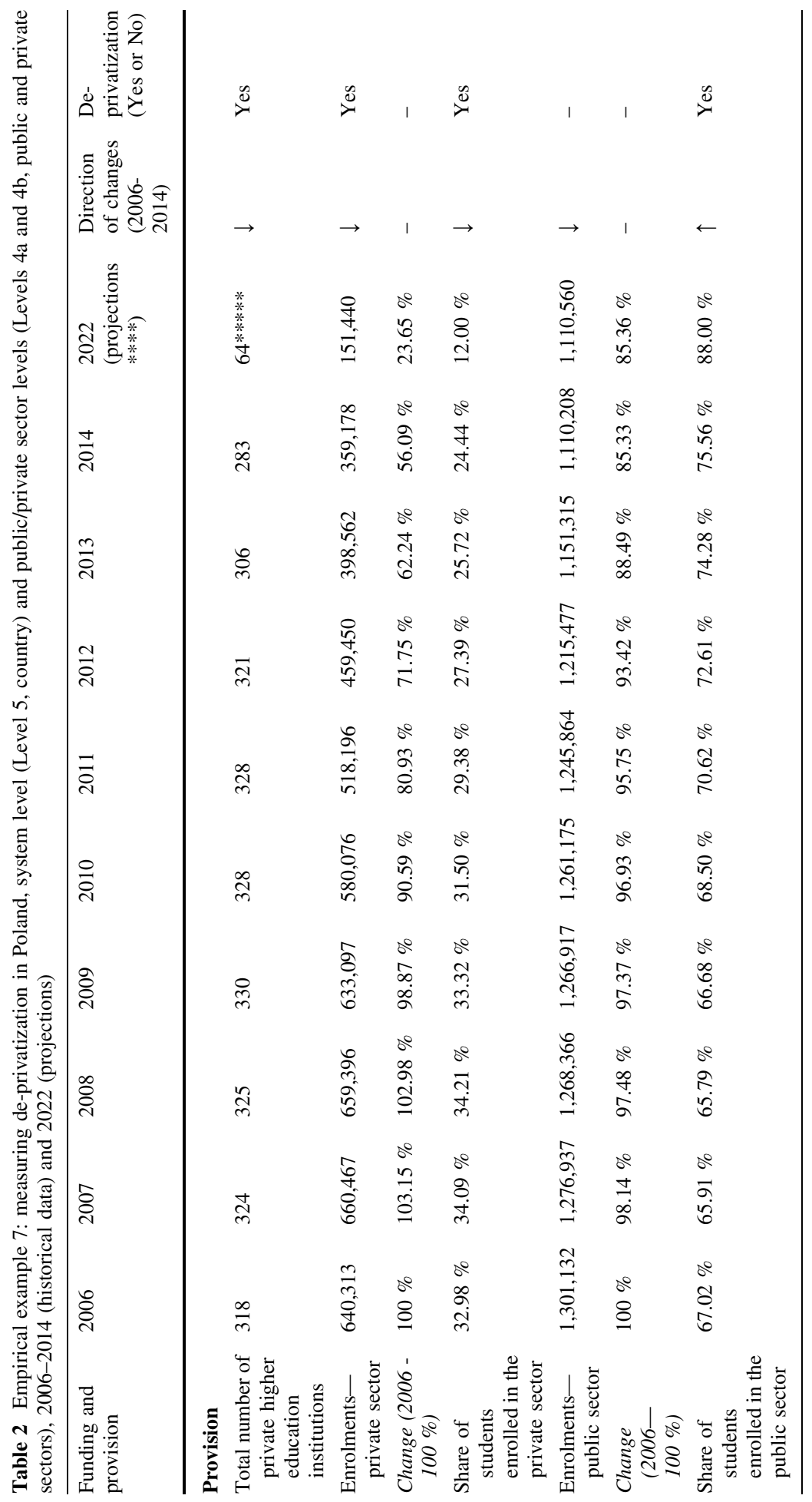




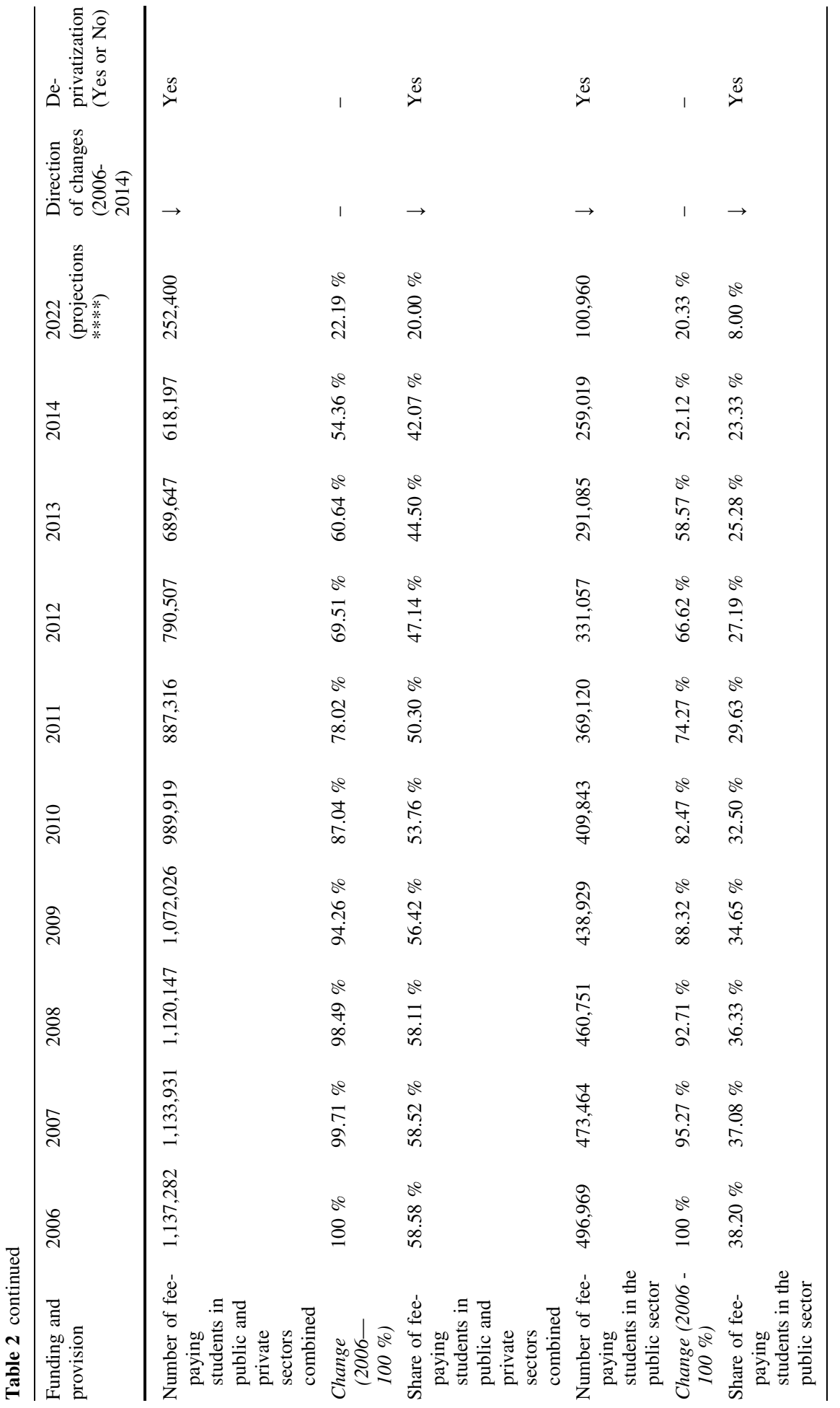




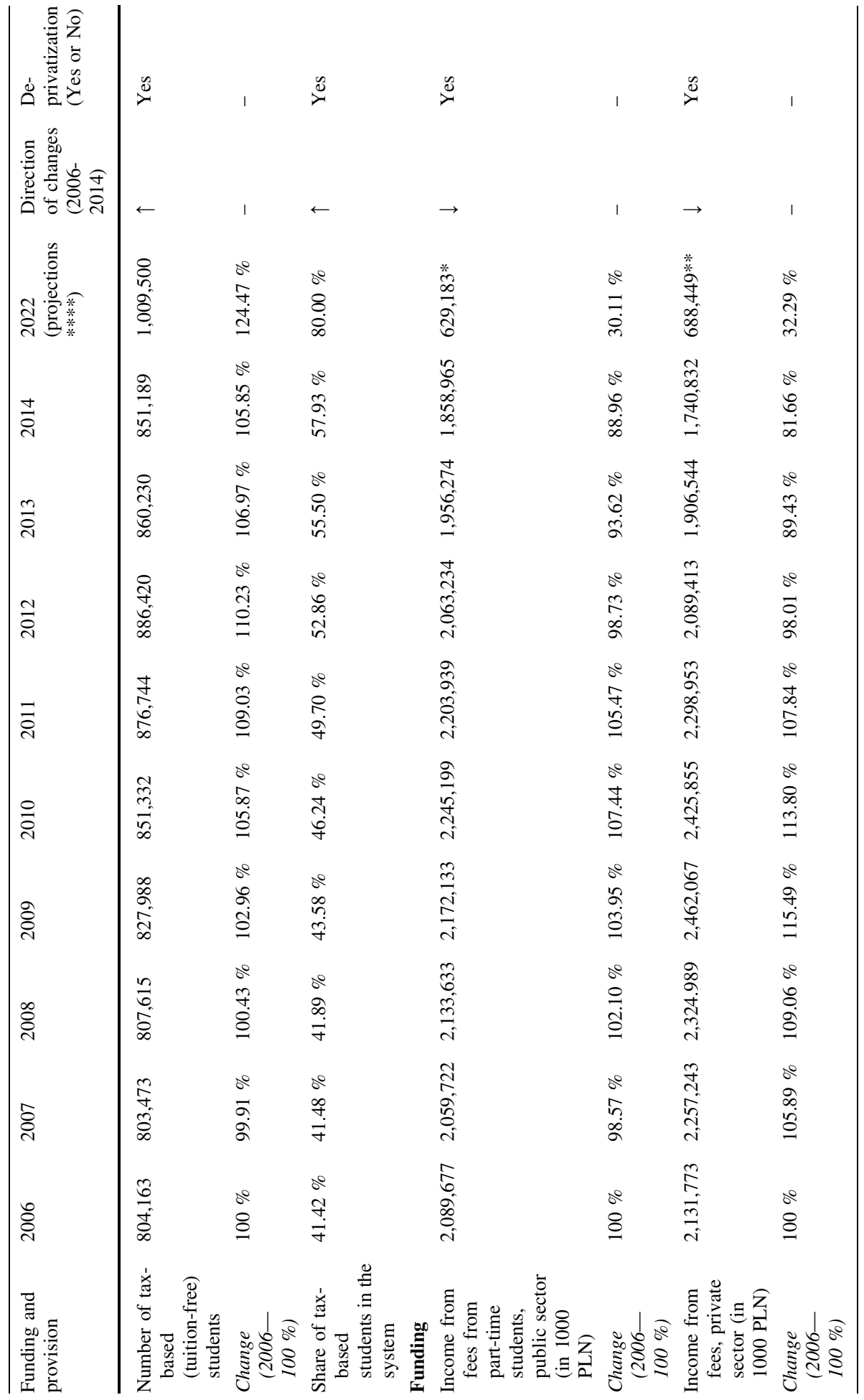




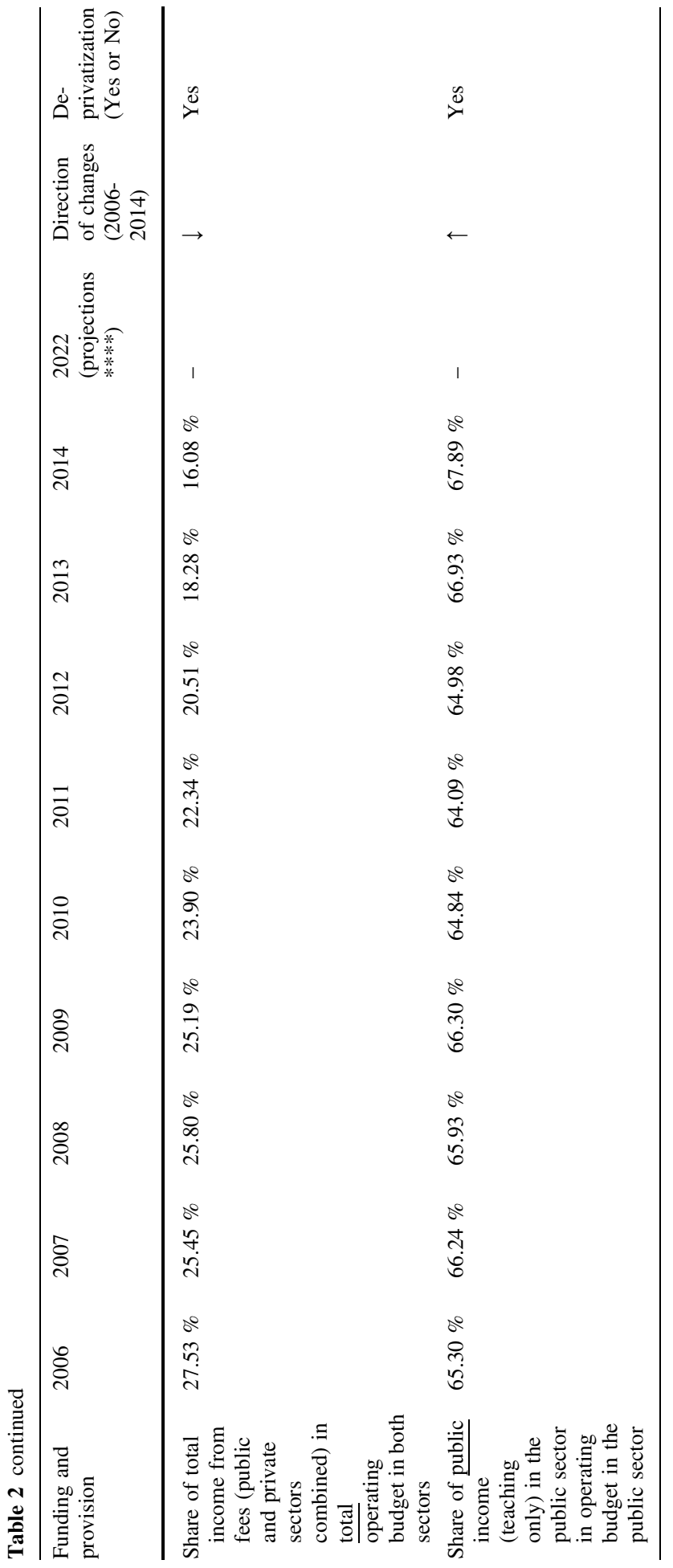






Springer 




Fig. 6 Empirical example 5: De-privatization at Level 5 (country). Share of total income from fees (=private funding, public and private sectors in Poland combined) in total operating budget in both sectors, 2006-2014. Own calculations based on GUS (2015) and its previous editions

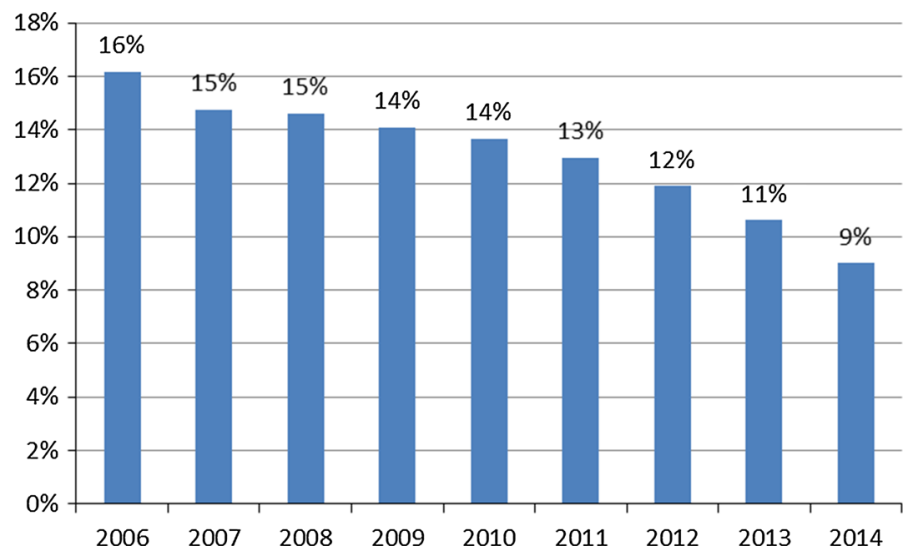

Fig. 7 Empirical example 6: De-privatization at Level 4a (public sector). Share of total income from fees in (=private funding) the public sector in operating budget of the Polish public sector, 2006-2014. Own calculations based on GUS (2015) and its previous editions

While at the aggregated country level (Level 5 in my classification in fourth section), de-privatization has been in progress in the region for about a decade now, at the disaggregated level of individual institutions (Level 2) it has occurred in different places with different speeds. And the speed and the direction of changes at the lower level of faculties (Level 1) may have been different. Taking the University of Warsaw (UW) as an example, in 2007-2013 the share of private funding (fees from part-timers) in total operating budget decreased from 19.37 to $11.26 \%$ (see "Funding" on the horizontal axis in Fig. 8), and the share of fee-based students in its student body decreased from 44.72 to $31.44 \%$ (see "Provision" on the vertical axis; arrows indicate the direction of changes). At the still further disaggregated level of faculties, though, de-privatization was accompanied in selected places by privatization: among the three faculties of UW with the highest income from fees (Faculty of Journalism and Political Sciences, Faculty of Law and Administration, and Faculty of Management), the first one lost almost 50 percent of its income, the 
Fig. 8 Empirical example 8: Deprivatization at Level 2 (individual university): the University of Warsaw, the share of private funding (fee-based, horizontal) in total operating budget and the share of private enrolments (fee-paying students, vertical) in total enrolments, 2007 (black) and 2013 (gray). Arrows indicate the direction of changes. (Color figure online)

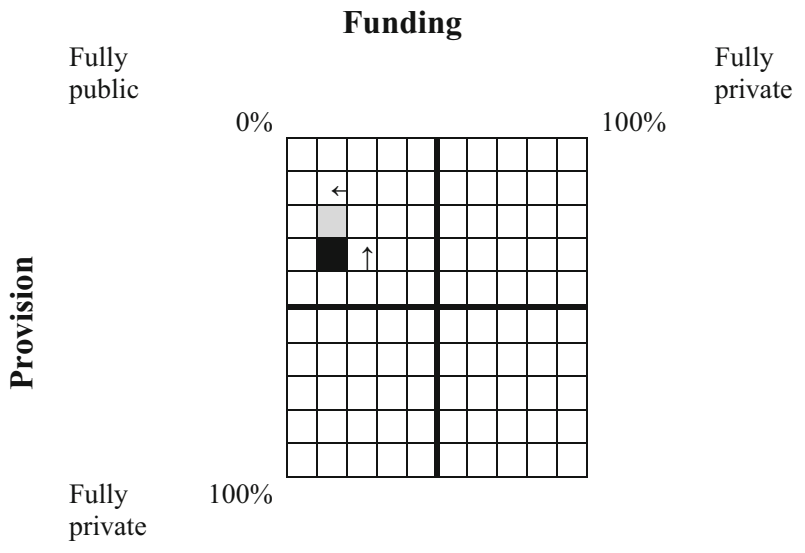

second slightly increased the level of it, and the third increased its level almost three times in the same period of 2007-2013: faculty incomes from fees were 20, 20, and 7 million PLN in 2007-and 11, 22, and 20 million PLN in 2013 (1 USD = 3.90 PLN; Szadkowski 2015: 25). Thus changing interests of fee-paying part-time students led to de-privatization in provision and funding in the first faculty but not in the other two. At the aggregated university level of UW, de-privatization is thus a dominating trend, albeit with different degrees and directions of changes in different faculties (there are changing mixes of "publicness" and "privateness" over time in different university units). Consequently, in general terms, national trends (Level 5), necessarily viewed in the context of public/private sector trends (Levels $4 \mathrm{a}$ and $4 \mathrm{~b}$ ), may conceal more differentiated institution-level trends (Level 2), and even more differentiated trends and countertrends at the faculty level (Level 1). For various countries in the region, one can provide empirical examples at various levels of analysis.

\section{Conclusions}

In this paper, several aims have been achieved: a new conceptual tool of de-privatization was developed for use in higher education research and policy, and it was briefly shown how to operationalize and measure it. Three previously separate strands of research (on privatization, private higher education, and cost-sharing) have been synthesized and explored as forming the global privatization agenda. The traditional dichotomous pairing of the public and the private has been shown to still be useful in specific empirical contexts, despite it becoming blurred globally. Major approaches to privatization in higher education over the last two decades have been rethought and redirected toward de-privatization.

The global processes of privatization and expansion in higher education have not been found to fit the ongoing demography-induced processes in post-communist systems in Central Europe very well. Instead of the conceptual pairing of expansion and privatization-the region has been found to be better served by the pairing of contraction and deprivatization. An empirically informed notion of de-privatization has been developed and its usefulness has been briefly tested in explaining the ongoing and expected shifts in higher education in the region. 
The processes of de-privatization have been defined as the decreasing role of the private component in the changing public-private dynamics. But they can also be defined as the increasing role of the public component in it (and then termed re-publicization). Deprivatization and re-publicization in higher education, being the two sides of the same coin, may serve to be used in different contexts. In the case of the region, de-privatization better serves the analytical purposes of understanding the impact of demography-driven contraction, if only for the historical reason that privatization used to be the key concept to understand expansion in the post-1989 period.

Acknowledgments I gratefully acknowledge the support of the National Research Council (NCN) through its MAESTRO grant DEC-2011/02/A/HS6/00183 (2012-2017). I would like to thank Simon Marginson and Anna Smolentseva for their invitation to a conference on "High Participation Systems" in HSE, Moscow, September 2013, where my draft approach to de-privatization was first presented. My thinking about the public-private dynamics in general has also been heavily influenced by a decade of collaboration and exchanges with Daniel C. Levy, the PROPHE (The Program for Research on Private Higher Education) Director at SUNY-Albany, for which I am very grateful. Traditional disclaimers certainly apply.

Open Access This article is distributed under the terms of the Creative Commons Attribution 4.0 International License (http://creativecommons.org/licenses/by/4.0/), which permits unrestricted use, distribution, and reproduction in any medium, provided you give appropriate credit to the original author(s) and the source, provide a link to the Creative Commons license, and indicate if changes were made.

\section{References}

Altbach, P. G., Reisberg, L., \& Rumbley, L. E. (2010). Trends in global higher education: Tracking an academic revolution. Rotterdam: Sense.

Belfield, C. R., \& Levin, H. M. (2002). Education privatization: Causes, consequences and planning implications. Paris: UNESCO.

Calhoun, C. (2011). The public mission of the research university. In D. Rhoten \& C. Calhoun (Eds.), Knowledge matters. The public mission of the research university (pp. 1-33). New York: Columbia UP.

Curaj, A., Deca, L., Egron-Polak, E., \& Salmi, J. (Eds.). (2015). Higher education reforms in Romania. Dordrecht: Springer.

Eckel, P. D., \& Morphew, C. C. (2009). Toward a clearer understanding of privatization. In C. C. Morphew \& P. D. Eckel (Eds.), Privatizing the public university. Perspectives from across the academy (pp. 181-192). Baltimore: The Johns Hopkins UP.

Enders, J., \& Jongbloed, B. (Eds.). (2007). Public-private dynamics in higher education. Expectations, developments and outcomes. Bielefeld: transcript.

Feigenbaum, H., Henig, Heffrey, \& Hamnett, C. (1998). Shrinking the state. The political underpinnings of privatization. CUP: Cambridge.

Fryar, A. H. (2012). What do we mean by privatization in higher education? In J. C. Smart \& M. B. Paulsen (Eds.), Higher education: Handbook of theory and research (Vol. 27, pp. 521-547). Dordrecht: Springer.

Geiger, R. L. (2007). The publickness of private higher education. In J. Enders \& B. Jongbloed (Eds.), Public-private dynamics in higher education. Expectations, developments and outcomes (pp. 139-155). Bielefeld: transcript.

Gómez, R. R., \& Ordorika, I. (2012). The Chameleon's Agenda: Entrepreneurial adaptation of private higher education in Mexico. In B. Pusser, K. Kempner, S. Marginson, \& I. Ordorika (Eds.), Universities and the public sphere (pp. 219-242). New York: Routledge.

GUS. (2015). Higher education institutions and their finances in 2014. Warsaw: Main Statistical Office (and previous editions).

Heller, D. E., \& Callender, C. (Eds.). (2013). Student financing of higher education. A comparative perspective. London: Routledge.

Ikenberry, S. I. (2009). Privatizing the public research university. In C. C. Morphew \& P. D. Eckel (Eds.), Privatizing the public university. Perspectives from across the academy (pp. 1-6). Baltimore: The Johns Hopkins UP. 
Johnstone, D. B. (2000). Privatization in and of higher education. www.gse.buffalo.edu.

Johnstone, D. B. (2006). Financing higher education. Cost-sharing in international perspective. Boston: CIHE.

Johnstone, D. B., \& Marcucci, P. (2010). Financing higher education worldwide. Who pays? Who should pay?. Baltimore: The Johns Hopkins UP.

Kaplan, G. (2009). Governing the privatized public research university. In C. C. Morphew \& P. D. Eckel (Eds.), Privatizing the public university. Perspectives from across the academy (pp. 109-133). Baltimore: The Johns Hopkins UP.

Kwiek, M. (2012). Changing higher education policies: From the deinstitutionalization to the reinstitutionalization of the research mission in Polish Universities. Science and Public Policy, 39, 641-654.

Kwiek, M. (2013). From system expansion to system contraction: Access to higher education in Poland. Comparative Education Review, 57(3), 553-576.

Kwiek, M. (2015a). The internationalization of research in Europe. A quantitative study of 11 national systems from a micro-level perspective. Journal of Studies in International Education, 19(2), 341-359.

Kwiek, M. (2015b). The unfading power of collegiality? University governance in Poland in a European comparative and quantitative perspective. International Journal of Educational Development, 43, 77-89.

Kwiek, M. (2015c). Academic generations and academic work: Patterns of attitudes, behaviors and research productivity of Polish academics after 1989. Studies in Higher Education, 40(8), 1354-1376.

Kwiek, M. (2016a). From privatization (of the Expansion Era) to de-privatization (of the Contraction Era). A national counter-trend in a global context. In S. Slaughter \& B. J. Taylor (Eds.), Higher education, stratification, and workforce development. Competitive advantage in Europe, the US and Canada (pp. 311-329). Dordrecht: Springer.

Kwiek, M. (2016b). From growth to decline? Demand-absorbing private higher education when demand is over. In M. Shah \& S. Nair (Eds.), A global perspective of private higher education (pp. 53-80). New York: Elsevier.

Kwiek, M. (2016c). The European research elite: A cross-national study of highly productive academics across 11 European systems. Higher Education, 71(3), 379-397.

Le Grande, J., \& Robinson, R. (Eds.). (1984). Privatisation and the welfare state. London: Unwin Hyman.

Levy, D. C. (1986). Higher education and the state in Latin America. Private challenges to public dominance. Chicago: The University of Chicago Press.

Levy, D.C. (2008). Private higher education's global surge: Emulating US patterns? In C. Diament \& R. Feldman (Eds.), Proceedings of the international conference: Privatization in higher education (pp. 32-52). Haifa: The Samuel Neaman Institute.

Levy, D. C. (2013). The Decline of private higher education. Higher Education Policy, 26, $25-42$.

Marcucci, P. (2013). The politics of student funding policies from a comparative perspective. In D. E. Heller \& C. Callender (Eds.), Student financing of higher education. A comparative perspective (pp. 9-31). New York: Routledge.

Marginson, S. (1997a). Markets in education. St Leonards: Allen and Unwin.

Marginson, S. (1997b). Imagining Ivy: Pitfalls in the privatization of higher education in Australia. Comparative Education Review, 41(4), 460-480.

Marginson, S. (2007). The public/private divide in higher education: A global revision. Higher Education, $53,307-333$.

Marginson, S. (2016a). Foreword: The partial shift from public to private goods in UK higher education. London Review of Education, 14(1), 4-10.

Marginson, S. (2016b). Global stratification in higher education. In S. Slaughter \& B. J. Taylor (Eds.), Higher education, stratification, and workforce development. Competitive advantage in Europe, the US and Canada (pp. 13-34). Dordrecht: Springer.

Marginson, S. (2016c). Public/private in higher education: A synthesis of economic and political approaches. Studies in Higher Education. doi:10.1080/03075079.2016.1168797.

McLendon, M. K., \& Mokher, C. G. (2009). The origin and growth of state policies that privatize higher education. In C. Morphew \& P. D. Eckel (Eds.), Privatizing the public university. Perspectives from across the academy (pp. 7-32). Baltimore: The Johns Hopkins UP.

Mok, K. H. (2011). Liberalization of the privateness in higher education. In P. N. Teixeira \& D. D. Dill (Eds.), Public vices, private virtues? Assessing the effects of marketization in higher Education (pp. 19-43). Dordrecht: Springer.

Morphew, C. C., \& Eckel, P. D. (Eds.). (2009). Privatizing the public university. Perspectives from across the academy. Baltimore: The Johns Hopkins UP.

Neave, G. (2008). Now you see it, now you don't: Privatization as the will-o'-the-wisp in the higher education policies of Western Europe. In C. Diament \& R. Feldman (Eds.), Proceedings of the 
international conference: Privatization in higher education (pp. 53-87). Haifa: The Samuel Neaman Institute.

Nelson, J. M., Tilly, Ch., \& Walker, L. (Eds.). (1997). Transforming post-communist political economies. Washington: National Academy Press.

OECD. (2014). Education at a glance. OECD indicators. Paris: OECD.

OECD. (2015). HEInnovate rewviews. Universities, entrepreneurship and local development. Country-level review Bulgaria. Paris: OECD.

Painter, M., \& Mok, K. H. (2008). Reasserting the public in public service delivery: The de-privatization and de-marketization of education in China. Policy and Society, 27, 137-150.

Priest, D. M., \& St John, E. P. (Eds.). (2006). Privatization and public universities. Bloomington: Indiana UP.

Sanyal, B. C., \& Johnstone, D. B. (2011). International trends in the public and private financing of higher education. Prospects, 41, 157-175.

Slantcheva, S., \& Levy, D. C. (Eds.). (2007). Private higher education in post-communist Europe: In search of legitimacy. New York: Palgrave.

Smolentseva, A. (2016). Universal higher education and positional advantage: Societ legacies and neoliberal transformation in Russia. Higher Education. On-line 21 April 2016.

Spulber, N. (1997). Redefining the state: Privatization and welfare reform in industrial and transitional economies. Cambridge: CUP.

Starr, P. (1989). The meaning of privatization. In S. B. Kamerman \& A. J. Kahn (Eds.), Privatization and the welfare state (pp. 15-48). Princeton UP: Princeton.

Szadkowski, K. (2015). University of Warsaw. Institutional Report. Poznan: CPPS.

Teixeira, P. N. (2012). The changing public-private mix in higher education: Analysing Portugal's apparent exceptionalism. In G. Neave \& A. Amaral (Eds.), Higher education in Portugal 1974-2009 (pp. 307-328). Dordrecht: Springer.

Teixeira, P. N., Johnstone, D. B., Rosa, M. J., \& Vossensteyn, H. (Eds.). (2006). Cost-sharing and accessibility in higher education: A fairer deal?. Dordrecht: Springer.

Thornton, M. (2012). Privatising the public university. The case of law. New York: Routledge.

Toutkoushian, R. (2009). An economist's perspective on the privatization of public higher education. In C. Morphew \& P. D. Eckel (Eds.), Privatizing the public university. Perspectives from across the academy (pp. 60-87). Baltimore: The Johns Hopkins UP.

Walker, A. (1984). The political economy of privatisation. In J. Le Grande \& R. Robinson (Eds.), Privatisation and the welfare state (pp. 19-44). London: Unwin Hyman.

Wang, L. (2014). The road to privatization of higher education in China. A new cultural revolution?. Dordrecht: Springer.

Whitty, G., \& Power, S. (2000). Marketization and privatization in mass higher education. International Journal of Educational Development, 20, 93-107.

Williams, G. (1996). The many faces of privatization. Higher Education Management, 8(3), 39-56.

Williams, G. (2016). Higher education: Public good or private commodity? London Review of Education, 14(1), 131-142.

Zusman, A. (1999). Challenges facing higher education in the twenty-first century. In P. G. Altbach, R. O. Berdahl, \& P. J. Gumport (Eds.), American higher education in the twenty-first century (pp. 115-161). Baltimore: Johns Hopkins UP. 